\title{
Incorporating Human Rights Concepts in Palestinian Mathematics Text Box: A Proposed Mechanism
}

\author{
Dr. Muneer Jebreel Karama \\ Assistance Professor \\ College of Applied Science, University Graduates Union \\ Palestine Polytechnic University \\ PO Box 198, Palestine, West Bank, Hebron \\ E-mail: muneerk@ppu.edu
}

Accepted: September 24, 2012 Published: October 31, 2012

Doi:10.5296/ijld.v2i5.2598 URL: http://dx.doi.org/10.5296/ijld.v2i5.2598

\begin{abstract}
This paper Submitted as enrichment material on the possibility of integration of the principles of human rights in Palestinian mathematics text boxes, with a view to sensitizing child rights, through the integration of human rights principles in some sections of Math such as: Set Theory, Geometry, Statistics, Probability, and Problem Solving, So it is an integral new contribution to this paper which is directed to Palestinian Ministry of Education to study, and highlighted the issue of citizenship, human rights on Palestinian Math Curriculums' .
\end{abstract}

Keywords: Human Rights Principles, Mathematics, Set-Theory, Geometry, Statistics, Probability, Problem Solving, Citizenship, Palestinian Math Text Boxes.

\section{Introduction}

Setup Palestinian student requires companies to keep pace with rapid changes, accommodation with the world represents a small village of based education programs and institutions to help students to adapt to this Community rapid change through for solving the problems faced by himself through peaceful and tolerance methods, So it's necessary speedier adequacy for students to be literacy (linguistic) and numeracy (mathematical) which is the foundations of citizenship, and must be defined uphold his rights and exercise it. These challenges reflected in the performance of the Education Department in the Palestinian Ministry of Education, with attention both students and about their rights through the draft human rights, development of this trend to the students, and to integrate human rights in school curricula all (not the specific articles only such as Arabic or Religion), until the value of exercise on the ground by other important subjects such as Math. 
Palestinian Ministry of Education in the West Bank play important part of human rights, through human resources and tangible, as well as many enrichment substances of human rights, stories, worksheets, Islamic, social, and Arabic, tend to merge these rights in the material, but not in Math.

It is surprising merged human rights in scientific articles such as Math, which is the important materials in the lives of students and intellectual process questioned the possibility of merged in such items, has found ample energy fertile recruit these rights in this article task (mathematics).

\subsection{Mathematics for All and no Childs left behind}

Mathematics is the building of reasoning and thinking so thought, contributed to generate many old and new civilizations, unfortunately some belief that mathematics, is very complex and difficult such as mathematics, also some believes that it is clever students Aokashe et al (1990).But these beliefs will demolish step by step because of human rights which is " Math for All ", and slogans such as No Child Left Behind (The White House, n.d.) and everyone is very important in combination, everybody counts (Mathematical Sciences Education Board and the Board on Mathematical Sciences, National Research Council, n.d.).

Classroom is the place and the time where the teachers interact within students, this interaction is very important because it's planed carefully by the teachers to achieve the set goals, and to build values to their students.

Student appears different ways of thinking, and behaviors through his or her engaged in tasks which the result may be okay or misunderstanding, and the teacher effectively mentored, guided, directed, and created conditions that will maximize students learning by means of democratic climate in his or her classroom can flowing steps Karama(2003):

i) Students thinking and mistakes accepted and respected by their teachers.

ii) To be patient, and justice for all students.

iii) To respect the views of the students until if these views are trivial or naïve and no theme mock.

iv) To provide the students with sufficient and running time for thinking, and not answer by teachers instead of students.

v) Employing an effective manipulative for each student, which evoke thinking skill, i.e. right to learning by doing?

vi) Provide opportunities and conditions for students to build their mathematical knowledge, i.e. right to discover math.

vii) Provide equity for all students without exception according to their religion or ethnicity or de-politicize, i.e. equity rights.

viii) Use diversification methods of teaching, learning, and evaluation- measurement such as written test, oral test, mental test, checklist, monitoring lists tests, reports, essay, short research, computer and Internet.

ix) Encourage competitions and Math clubs, i.e. right to belong.

x) Encourage Math puzzle, which highlights the thinking skills of the students.

xi) Employment of Math play, and arts in every day lessons, i.e. right to play, and learn from playing.

xii) Use Math stories in lessons, i.e. right to learn by exiting.

\subsection{The following steps may be effective for teaching human rights in Math}

- Include Math tests with items of human rights.

- Include plans with objects, aims, and standards of human rights. 
- Design worksheet, and development material with human rights.

- Discuss human rights in every Math lessons.

\subsection{Mathematical content and human rights}

Table 1. Includes a group of Human Rights Roncepts (HRC) Jubran (2005):

\begin{tabular}{|l|l|l|l|}
\hline Item No. & HRC & Item No. & HRC \\
\hline 1 & Tolerance & 11 & Freedom \\
\hline 2 & work & 12 & family formation \\
\hline 3 & dignity & 13 & Life \\
\hline 4 & equality & 14 & $\begin{array}{l}\text { humanitarian } \\
\text { treatment }\end{array}$ \\
\hline 5 & security & 15 & Citizen \\
\hline 6 & protection & 16 & Solidarity \\
\hline 7 & education & 17 & Ownership \\
\hline 8 & participation & 18 & social security is \\
\hline 9 & $\begin{array}{l}\text { responsibility } \\
\text { carries }\end{array}$ & 19 & $\begin{array}{l}\text { salvation from the } \\
\text { oppression }\end{array}$ \\
\hline 10 & legal prosecution & & \\
\hline
\end{tabular}

\section{The Mathematical branches which are suitable for incorporating human rights}

\subsection{Set Theory}

We can teach students human rights concepts through set theory, so We can treat the items of human rights as a finite group, also we can represent it in Venn diagrams, and perform the operations such as union, intersection, belongs, etc, as we can see on the following examples: * Let $\mathrm{A}=\{$ freedom, solidarity, dignity, security, protection $\}$, answer the following questions:

a) How many elements (or members) the set A contains?

b) Represent A for Venn scheme.

c) Write A by different way.

d) How many subgroups A contains? Write all of them.

* Let $\mathrm{X}=\{$ dignity, freedom, equality, solidarity, justice $\}, \mathrm{Y}=\{$ dignity, freedom, equality $\}$, and $Z=\{$ freedom, justice $\}$, answer the following:

a) $\mathrm{Z}, \mathrm{Y}, \mathrm{Z}-\mathrm{Y}, \mathrm{Y}-\mathrm{Z}, \mathrm{Z} \cup \mathrm{Y}, \mathrm{Y} \cap \mathrm{Z}, \mathrm{X}, \quad \mathrm{Z} \cup \mathrm{Y}, \quad \mathrm{Y} \cap \mathrm{Z}$.

b) True or false: $\quad$ freedom $\notin X, \quad Z \supseteq X$.

\subsection{Statistics}

We can teach students human rights through statistics, the students can manage the diagrams and interpret it, also students can calculate mean, median, mod, standard deviation, etc, the following example shows the result of the election of the $7^{\text {th }}$ grade for Student-Parliament. 


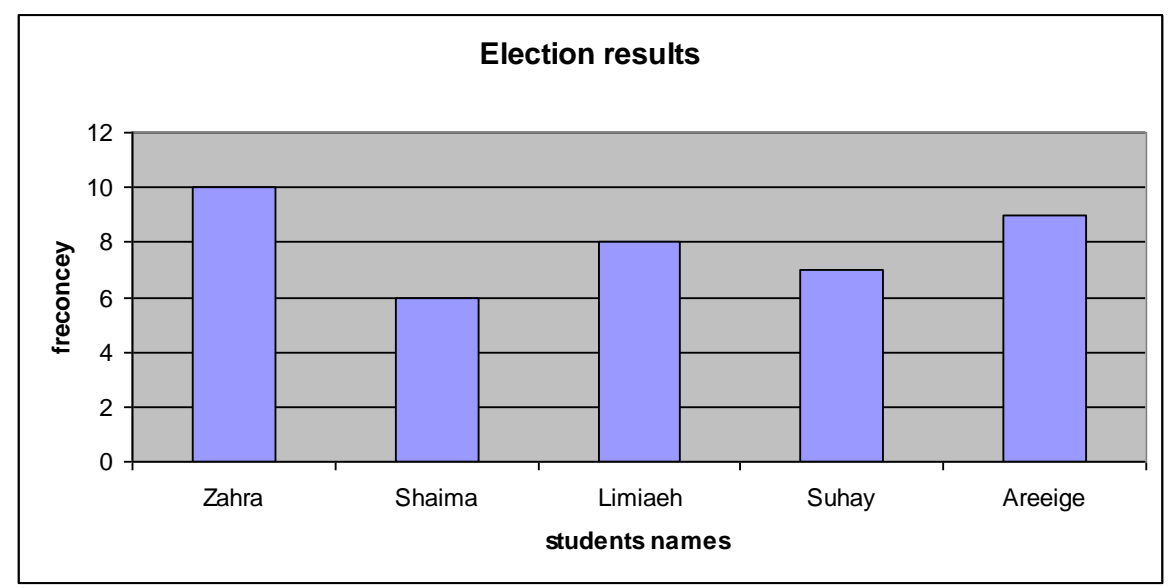

Figure 1. The result of the election of the $7^{\text {th }}$ grade for Student-Parliament.

Answer the following question

- How many students are voting?

- What is the name of the winner candidate?

- What is the name of the lowest votes?

- Find the sum of the total voting for Sahima, and Limiahe.

- Find the mean of all voting.

- What is the mod?

- Find the median, and deviation?

- What is the right that students play in this task?

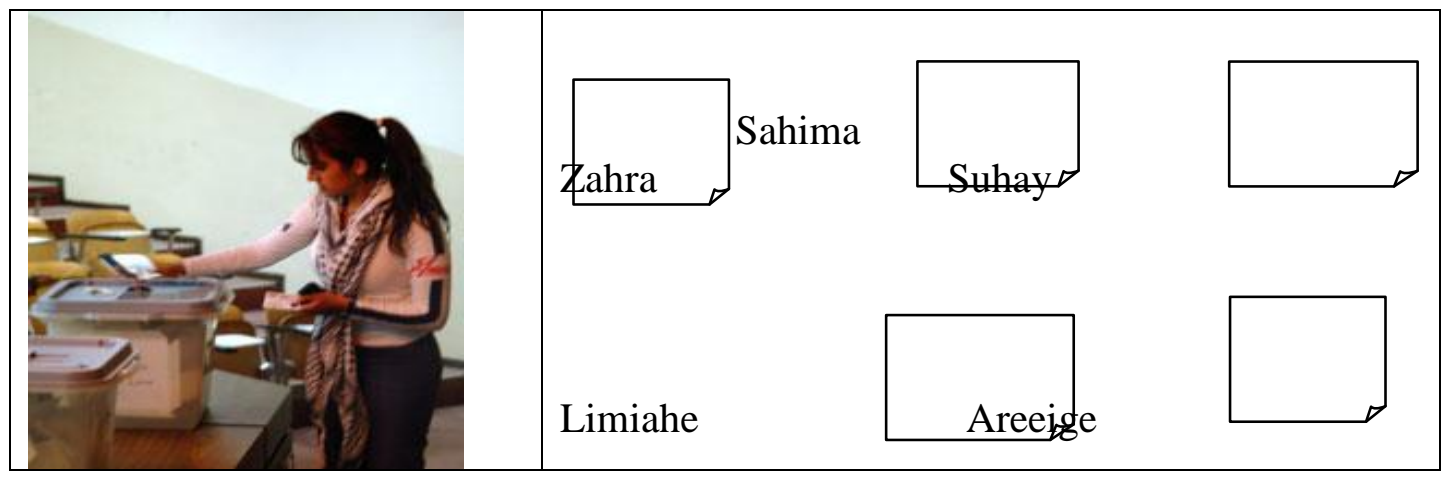

Figure 2. The picture of Areeige during the voting.

\subsection{Probability}

We can teach students human rights through probability, the students can solve problems and find probability for such situations as follows:

a) Assume you have five cards written on it \{dignity, freedom, equality, solidarity, justice\}, if you pullout a card what is the probability to have (dignity) card? What are the possible outcomes of this experiment?

b) If we toss a con that's written on its face (solidarity), and on the back (tolerance), what are the outcomes of this experiment? If we toss the con three times what is the probability to have (solidarity)?

c) Suppose that we have a regular die his faces marked by f freedom, solidarity, dignity, security, protection, education \}, we toss it one time, draw this experiment by a tree method, what is the probability that (education) will appear?

\subsection{Geometry}


we can learn student's human rights concepts on geometry lessons through drawing shapes and naming it by replacing the symbols of human right concepts as follows:

a) Connect between the concepts and state the name of geometry output figures

Security *

Equality *
* Freedom

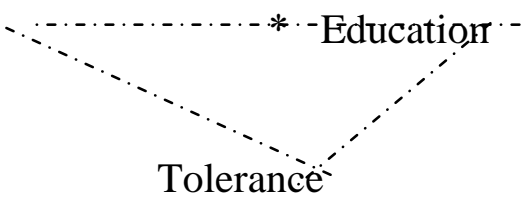

Figure 3. Geometrics examples.

\subsection{Problem Solving}

it considers an important issue for teaching and learning human rights, and the students can use their skills like mediation, and pressure- crowded to resolve the conflicts that occurs on their schools.

\section{Recommendations}

- Conduct training workshop for teachers, and students about human rights on Math.

- Preparations, evaluation, and distributions of enrichment material.

- More researches, and conferences to study the effect, and impact of teaching and learning human rights on Math.

- More focus from the Palestinian Ministry of Education to merge human rights on Math 


\section{References}

Aokashe et al. (1990). History of mathematics, Al-Mustaqbal for publications, Amman, Jordan.

Jubran, W. (2005).Training Material for human rights, UNRWA, West-Bank, Field Education Office, Jerusalem.

Karama, M. (2003) . Human Rights on Mathematics,Biennial Work Plan - 1, Activity No : 1 . B . 10.4.1, UNRWA HQ, Amman, Jordan.

Mathematical Sciences Education Board and the Board on Mathematical Sciences, National Research Council (n.d). Everybody Counts:. A Report to the Nation on the Future of Mathematics Education. Retrieved October 20, 2006, from http://www.nap.edu/catalog/1199.html.

The White House (n.d.). No child left behind. Retrieved January 30, 2008, from http://www.whitehouse.gov/news/ reports/no-child-left-behind.html. 